\title{
The Role of Instructional Resources amongst Social Studies Teachers in Nigeria: The Quest for Effectiveness in Classroom Pedagogy
}

\author{
Sunday David Edinyang
}

Abigail Ojong Ejoh

Amina Peter Adams

Department of Social Science Education, Faculty of Education, University of Calabar, Calabar, Nigeria

Doi: 10.36941/jesr-2020-0036

\begin{abstract}
This paper aims at discussing the role, awareness and use of instructional materials/resources as a prerequisite for attaining effective social studies education in Nigeria. In doing this a conceptual clarification of the concept of social studies education as given by experts in the field was taken. The origin of social studies in Nigeria was analyzed. The objectives of social studies education at the post-primary education level and its characteristics were discussed. The concept of Social Studies instructional materials and resources were elaborated. A critical look was taken at instructional materials and its types as well as their relevance to Social Studies education. A look was also taken at constrains of utilization of instructional materials and resources. Criteria for selecting materials and resources for Social Studies classroom as well as sources of social studies resources instructional materials were touched. Instructional materials for effectiveness in classroom pedagogy were carefully discussed. Recommendations were not left out.
\end{abstract}

Keywords: Instructional materials, Resources, Teachers, Pedagogy, Classroom

\section{Introduction}

Modern curriculum trend in social studies education over the years have received considerable attention from teachers and professionals of social studies education. This trend circulates the notion that the introduction of modern curriculum to social studies education will help solve problems created by traditional methods of teaching which has been bedeviling curriculum programmes in our schools. Social studies in this new dispensation is purposed at integrating and inculcating of knowledge and inspiration from many areas of learning. It is very important for any prospects for eminent improvements in the pedagogy of modern social studies. Social studies must be dictated by a wide range of understanding that knowledge from any one discipline is too limited to enable an individual to fully understand the complexity of the human behavior and make a reflective decision on both public and personal grounds.

It has become an affair that the countless linked subjects such as sociology, geography, economics, political science, history, anthropology etc. needs to feature in the social studies content 
and programmes, theories from these disciplines constitutes the curriculum basis of the subject area. These subjects essentially constitute the content or handling central issues or problems which social studies, as a subject, cannot afford to dispense with and survive as a subject worthy of pursuit. Some of these important issues, according to the Nigeria national policy on Education (1981), includes the followings "a shared responsibility for the common good of society", "a cultivation of a sense of compassion for the less fortunate", "a cherishing of a sense of respect and tolerance for others", "a development of social approaches and values like 'honesty', 'trustworthiness', 'co-operation', 'interdependence', 'open-mindedness', 'diligence', “integrity”, , and 'obedience', 'an acquisition of outlooks and or approaches, that is acceptable to social, physical, cultural, and economic development' 'rationally', 'interaction amongst peoples', "loyalty and patriotism", "freedom and authority", "value-inquiry", "value-analysis" and "critical thinking",.

These concept which are gotten from a large varied disciplines, social sciences inclusive, do not only make-up the core of social studies education but they also represent important curricular artifacts necessary for an effective establishment of learning and behavioural objectives for students and learners in the subject area (Okam, 1989).

\section{Conceptual Clarification}

Social studies: Newness of social studies in Nigeria and generally in the Nigerian schools in particular, with various person, social studies educators, professionals and non-professionals has led to an overdose of the definitions of social studies, these various individuals have defined social studies from their personal perception, cultural backgrounds which have led to no consensus in its definition

Mezieobi (2011), cited in Edinyang (2018) viewed social studies as a important course of instruction which is intended to equip the student with the perception, values, attitude and the much needed skills to survive in an ever changing society, full of periodic changes in information know-how, values and awareness. Kissock (1981) defined social studies as a curriculum study which the society uses to inculcate in students the know-how, skills, attitudes plus action it sees as important concerning the relationship between human beings, their world and themselves. Dubey and Bath (1980), conceptualized social studies as "The process of education that deals with the study of individuals for the purpose of affording children and adults the occasion to practice and solve individual and social problems. Ololobou (1999) saw social studies as a structured, cohesive study of man and his environment, both physical and social, with emphasis on perception, practical skills and needed attitudes and response for the purpose of producing an effective citizenry. Wesley (1961), defines social studies as "The body of knowledge that deals with the study of man and his environment. Edinyang (2014) views social studies as the study of humanity, interactions of humans for peaceful coexistence, interdependence and interrelationships for effective living in the society.

\subsection{Social studies instructional materials}

These are teaching and learning facilities which enable or enhance the activities of teaching and learning. These are very vital teaching component that enhances teaching. Without these instructional materials, teaching and learning would not be effective, it is as good as no teaching at all.

Instructional materials are the rocks or pillars of result oriented teaching and learning process. For Ezegbe, (1988), instructional materials are seen as "teaching aid" while Uchegbu (1997) sees instructional materials as those carriers or conveyors of teaching information. Nwanyanwu (1999) cited in Edinyang (2014) said instructional materials are irrelevant, when they do not excite retention in the learner and have no immediate relevance to the immediate or remote needs of the learner. 


\subsection{Instructional resources}

According to Wikipedia, any pool of material, animate or inanimate articles, human and non-human resources a teacher could use in teaching and learning situation to produce the anticipated learning goals. They include prints: textbooks, pamphlets, handout, study guides, manuals.

\subsection{Electronic interactive: Computers, graphing, calculators, tablets.}

\section{The Origin of Social Studies}

The origin and the history of the discipline "social studies", is covered in obscurity. It is very difficult to understand its origin and history, due to the conflicting and divers accounts of writers on the subject matter. The divergent views on the origin and the beginning of social studies in the universe and Nigeria in particular which are unreliable and unrealistic views about social studies origin and history have created more confusion rather than give an accurate and throw more light on its origin. According to Joof (1991), social studies takes its root from the western sphere, perhaps Europe or Western Europe and North America.

Ezegbe (1987; 1988), Udoh (1989); Osakwe and Itedjere (1993) cited in Mezieobi (2008) hold a contrary opinion. To them, social studies originated from the United States of America. Osakwe and Itedjere (1993) cited in Mezieobi (2008) went further to point to the direction which the spread of social studies went. To them, from the United States of America, Social Studies found its way to Europe, especially Britain.

\subsection{The origin and history of social studies in Nigeria}

From the foregoing, one may possibly believe that social studies discipline was imported to Nigeria from Great Britain. Nigerian scholars, writers and professional are in disagreement as to what time social studies first became popular Nigeria or in Nigerian schools. According to Obilo (1981) and Ezegbe (1987) that the advent of social studies in Nigerian schools was in the early 1960's whereas Osakwe and Ifedjere holds the view that it was in 'mid 6o'sObede (1987) put it at the late 6o's. Adeyoyin (1982) cited in Mezieobi (2008) said social studies was birthed in Nigeria during the colonial era with the establishment of schools. According to her, social studies which the colonial masters introduced was couched in the then religious syllabus.

Mezieobi (1992) disagrees with the imported origin hypothesis of social studies and says that the attribution of the beginning of social studies to the colonial times is an error. To Mezieobi social studies has been right from its inception in Nigeria in the pre-colonial days or in Nigeria's indigenous time with its goals, content, methods and evaluation process, which met the needs and aspirations of the then Nigerian society and Nigerians. According Mezieobi (2008) what is new in the starting point of social studies in Nigeria is the concept social studies which was really borrowed and 'social studies' which became as a discrete topic in the Nigerian schools. Even today in Nigeria, the social studies content is Nigeria-specific as it focuses largely on the Nigerian environment and its lifestyle.

\subsection{Social studies objectives for primary schools}

Social studies at the primary school level is aimed at developing, empowering and equipping the learners or pupils to become effective and efficient individuals who will ensure that the Nigerian society norms and values are upheld in the face of adversity. According to Dubey et al (1980) cited in Ololobou, et al (200o). The aims of social studies at the primary level are spelt out clearly as thus;

(1) Creativity and self-confidence on the basis of understanding their own accomplishments, potentials and their individual value.

(2) Power of resourcefulness and imagination 
(3) Aspiration for the awareness and sustained learning

(4) Appreciation of the self-worth of man and liberty

(5) Compassion for the less fortunate

(6) Sense of reverence for and tolerance of the view of others even in contradiction

(7) Readiness to accept indispensable changes within a structure of law and order arising from the will of the society

(8) Approaches favourable to social, cultural, physical, and economic development which will empower the pupils to partake in the activities of the community and after they leave school to become reformers and achievers of good in society.

(9) Social approaches and values such as participation, cooperation, open-mindedness, honesty, interdependence, integrity, diligence, trustworthiness and obedience.

(10) Essence of national patriotism and consciousness by way of interest and participation in our indigenous, national and world heritage

(11) Social awareness and analytical judgment, as well as effective and constructive thinking.

\subsection{Social studies objectives for post-primary schools}

The objectives of social studies for post-primary school is geared towards ensuring that the students are in the know of the various problems confronting their nation or country or the world at large. It is also aimed at producing effective students who will appreciate the relationship that exist between people; hereby making them good ambassadors of their society in general. According to Durbey, et al (1980) cited in Ololobou, et al (2000) the objectives are as follows;

(1) To enable students be awake to the problems of his country in particular and of the world in general, and to appreciate the interdependence between people

(2) To create the understanding and consciousness of the growing social and physical environment, it's man-made, natural, spiritual and cultural resources, as well as with the rational practice of maintenance of these resources for development.

(3) To cultivate in the student a positive approach to citizenship and the desire to make a positive individual input to the establishment of a united Nigeria.

(4) To improve the ability to learn and to acquire skills vital to the development of a fitting professional life, that is pride in the job and sound decision making.

(5) To cultivate in the student an acceptance of his cultural heritage and a desire to preserve it.

\subsection{Goal of social studies}

Social studies goals have been seen to be divided in a variety of ways depending on the use in which the goal is being used, or employed. According to Mezieobi (20o8) seven (7) goals of social studies are outlined and they are as follows;

1. Instructive or knowledge and information goals: This goal focuses on transmitting or imparting knowledge or information that are social studies related or relevant. The knowledge or information that is not dormant but knowledge that can be utilized to equip one with one's social realities.

2. Reflective thinking goal: The utility value of any knowledge or information is the ability of the receiver of that information to digest, it analyze it, and apply it in the solution of problems, or in the creation of new knowledge through serious thinking. The ability of any knowledge to be functional is a product of reflective thinking process.

3. Affective goals: These entail the ability to develop in the recipient of social studies information, knowledge of content, positive values, attitude and feelings.

4. Citizenship transmission goal: This involves inculcating in the children socio-civic competences and all good citizenship entails.

5. Pupil self-enhancement goal: The ultimate focus of this goal of social studies is to equip the 
children with the psychological know-how to enable them feel committed to their society, feel a sense of being worthy members of the society who are bound to contribute to societal development.

6. Socio-political activism goal: This goal intends to make the pupil-student clientele active socio-political participant in his environment and who would resort to constructive social criticism when need be.

7. Skill's goal: By exposing children to social studies, they would acquire social skill, study skills and work habits, group work skill and intellectual skills.

\subsection{Characteristics of social studies}

The characteristics of social studies are very distinguishing in nature and unique in general. According to Mezieobi (2008) stipulated the followings as the characteristic of social studies to include thus;

1. Unlike the other field of study which see knowledge in their separateness or in a compartmentalized frame hence the discrete subject areas of the social sciences and the humanities, social studies sees knowledge and man's social world as an integral whole. In this way one gets to know how other people live in the real world exactly.

2. If social studies looks at man and his world or environments from a holistic perspective seeing the world as a whole, it then follows that knowledge, man's life and human behavior cannot be better understood in fragments.

Social studies, therefore adopts the integrated approach to knowledge by fusing or blending relevant content, concepts, methods and generalizations drawn from the other related disciplines or content areas of social studies in order to make the learner see the world as a whole, and in addition, "develop an integrated view of reality and free himself from the narrow confines of traditional social science discipline".

3. Social studies draws its content from or focus mainly on the social sciences, the humanities and from many other relevant sources including the experiences of the children.

4. Social studies in all parts of the world are largely society relative or society specific. In Nigeria, social studies is mainly Nigeria centric as it focuses mainly on the Nigeria environment but may refer to what is happening, in relation to social studies, in the globe other parts of the universe for purposes of emphasis or relevant comparison.

5. Social studies is socially or society sensitive. This implies that the discipline is a dynamic field of learning in a rapidly changing jet or technological world, social studies must keep pace with global changes particularly those affecting Nigeria, and must of necessity reflect the changes, as they occur, in the school, social studies syllabus or curriculum.

6. One very important characteristic of social studies is its emphasis on "classroom without walls" in the community.

7. Good social studies programme is activity loaded and predominantly contains activities to be done. The activity-packed characteristics of social studies make the learner an active participant in the teaching-learning process.

8. The goal-objects of social studies, simply put, are to produce accountable and participative citizens with critical, reflective skills and approaches to enable their environments produce all that's needed for right and successful living. The essence is to make the society a worthy human habitation with minimum of problems.

9. It is not all the teaching methods and techniques that to the effective teaching of social studies. Those teaching techniques cum methods that most appropriately contribute to the accomplishment of the methods, inquiry/discovery, role playing, simulation games, discussion, questioning methods, problem-solving and individualized instruction. 


\section{Social Studies Instructional Materials and Resources}

Any act of teaching which is done without instructional materials is said not to be correct or learning may also take place depending on what is being taught and the setting position in which it was taught. But when teaching is done effectively with the aid of an instructional material much learning is said to have taken place and the content retention is efficiently enhanced. A wide variety of people in the circle of social studies teachers exist in social studies classrooms. Most of these teachers are trained conventionally in the subject, such as Geography, Economics, History, Religion and Government etc. in the process of their professional training and development they were exposed to a variety of wide range of instructional materials and its usage which are not possibly known to the untrained social studies teachers in classrooms.

Contrary to this background, the trained professionals of social studies who are exposed and oriented in the demands of social studies instructional materials, its usage and development find it very expedient, to emphasize the types of instructional materials employed in teaching and learning of social studies.

\subsection{The use of instructional materials}

When teaching and learning the subject social studies, it is of importance that these instructional materials are used. The reasons for the use of instructional materials are thus;

1. It simplifies content, abstract and concept.

2. It brings what is been taught to the learners learning level.

3. It makes teaching and learning real.

4. It arouses the curiosity and interest of the learning in a bid to making teaching and learning effective in the classroom.

5. It makes teaching much easier and interesting to both teacher and learner.

6. It enables and enhances the retention capability of the learner, thereby making the learner to remember all that he/she has been taught in the classroom. According to Mezieobi (2008). He outlined why the use of instructional materials? The why or reasons are as follows;

a. Some instructional materials enable students to acquire experiences, knowledge that they would otherwise not have appreciated and understood by hearing only from the teacher.

b. The usage of the instructional materials that are available in the immediate environment of learners makes him appreciate the volume of nature's assistance to his learning effectiveness.

c. Instructional materials save the teacher a lot of time which may be employed in other facets of meaningful teaching and activities.

d. Some instructional materials make teaching reach a wide number of learner than sheer teaches presentation would have done given the astronomical rise in enrolment trends in our schools and student population explosion in the classrooms. In this way, the stress with teaching a large crowd of students would have entailed, is drastically minimized.

e. The usage of varied of instructional materials pleasantly accommodates differing learning behaviors of learners or their individual learning differences or pattern and background.

\subsection{Types of instructional materials in social studies}

For a result oriented teaching and learning of social studies in classroom pedagogy it is expedient to use a variety of instructional materials that will aid teaching and learning process. Jarolimela (1971) and Ikwumwlu (1988) cited in Mezieobi (1992) categorized instructional materials and resources. 
1. Visual material

2. Audio-visual materials which comprises of electronically operated and non-electronically operated materials. According to Nacino-Brown et al (1982 pps 167-168) cited in Mezieobi (2008) classified instructional materials and resources into four broad categories namely;

- Visual materials which they subdivided into seven (7) thus: flannel or felt-boards, thirddimensional materials, chalkboard, printed materials, bulletin boards, still picture (nonprojected and projected) and charts.

- Audio materials: Transistor (radio), tape recorders and record players.

- Audio materials: Television and motion images.

- Community resources.

Alaezi (1990) cited in Mezieobi (2008) classified instructional materials and resources into;

1. Textbooks

2. Blackboard and flannel board

3. Library

4. Audio-visual materials made up of five parts, namely;

- Two-dimensional materials: Pictures, diagrams, wall charts, time charts, maps/atlases.

- Three-dimensional materials: Models, diagrams, templates, specimens.

- Projected materials: Film Strips, slides, micro-projection, opaque projector and overhead projector.

- Audio-materials: Radio, computer tape recorder/tape recorded materials.

- Audio-visual materials: Television and radio-cassette television.

\subsection{Instructional materials and resources relevant to social studies}

Despite the various instructional materials and resources which are useable and useful in the teaching-learning processes and activities in general, there are certain material and resources which are most reliable and appropriate for efficacy of social studies instruction in Nigeria and Nigerian schools at all levels of education. Nigeria given the social importance and relevance nature of social studies and with the low-level of our technological growth, development and advancement of the Nigerian society and nation, it could be deduced that the growing emphasis on community-based education and the hard economic circumstances which has caused inadequate supply of instructional materials to institutions.

The syllabus which are suitable and appropriate to social studies teaching and learning in the Nigerian situation are large. According to Mezieobi (2008) outline the most relevant materials which are;

1. Graphic and chalkboard or two dimensional resources they include, graphs, diagrams, pictures, cartoons, posters, comics, bill boards, charts maps/atlases.

2. Reading materials

3. Audio-materials

4. Audio-visual materials

5. Community resources

1. Chalkboard: The chalkboard which is one of the oldest and most used of all visual materials is no longer very readily available as a result of high cost of materials for its construction, and constant resurfacing of the black surface. The result is that the poor condition of the chalkboard, coupled with the poor quality chalk used in the educational institutions results in inadequate utilization of the chalkboard for teaching interactive activities in social studies.

2. Reading materials: The conventional values associated with reading materials such as text books in teaching and learning have increasingly led to the delusion of people into the thinking that text books and other reading materials are indispensable in teaching and learning. According to Ikwumelu (1988) cited in Mezieobi (2008). 
3. Audio-materials: In general terms, radio broadcasting when properly utilized is an invaluable instructional material in social studies education, given the background materials to effective teaching and learning which they provide and the current information on social issues and problems which they disseminate, all of which enrich the social studies curriculum.

4. Audio-visual materials: Like radios, television is a very important instructional resource in social studies teaching and learning because of the values embodied in television programmes, and the extent to which these values have impact on the people.

5. Community resources: Since a very important characteristic of social studies is its social relevance. It's capacity to be consistent with the social realities, aspirations, philosophy, needs and wants of a given social milieu. Community resources, both human and nonhuman, which are currently neglected in social studies teaching and learning, seem to be the most important instructional resources in any effective teaching and learning activity in social studies education. According to Mezieobi (2008), community resources can be grouped in two broad categories. Human resources or resources persons and non-human resources.

i. Human resources include the following: community (traditional) leaders, farmers, hunters, fishermen, gardeners, mechanics, vehicle drivers and bus conductors, traders, carpenters, craftsmen, artists, blacksmiths, butchers, policeman, warders, legislators, musicians, priests, engineers, architects, modern or contemporary teachers functioning as guides in the teaching-learning process, librarians and postmen.

ii. Non-human resources include:

a) Health institutions e.g. maternities, clinic, hospitals.

b) Educational institutions e.g. schools, universities, colleges of educations and libraries.

c) Economic institutions e.g. markets, banks, industries, factories, farms, companies, bakeries, mechanical workshops.

d) Legal institutions e.g. courts, police stations.

e) Communication, post offices or postal agencies.

f) Political institutions e.g. the state assemblies, legislatures, local government authorities, traditional rulers, palace.

g) Recreational spots, such as; village halls, civic centres, swimming pools, theatres.

h) Historical places e.g. museums, ancient architectural designs and old buildings.

i) Transportation stations e.g., motor parks, airports, bust-stops, railway stations and docks.

j) Physical features e.g., lakes, streams, valleys, islands, hills.

k) Religious places, e.g. churches and mosques.

The list of resources places should be drawn from all walks of life. While, non-human resources should cover a wide range of social, economic, political, physical and environments.

4.4 Importance of community resources in social studies teaching and learning effectiveness in the classroom

Community resources enhances the effectiveness of teaching and learning in schools, as it will make the students to be aware of happening in their immediate, it will ease fatigue that is associated with classroom as students loves sightseeing. According to Mezieobi (1991) outlined eight reasons for the use of community resources in teaching and learning in classroom process.

(1) To expose the students to the realities of their environment or community and make them have direct experience which will help concretize the content that have been taught.

(2) To eliminate the boredom of constant setting, thereby facilitating learning.

(3) The community resources enables the community and the school to be linked in a closer 
relationship; the students are made to appreciate the fact that the community plays vital roles in their education and ultimately in their life.

(4) Community resources help to underscore the lazy social studies teachers, blame on the unavailability or lack of instructional materials as being instrumental to his students' poor performance in examination.

(5) Community resources save a great deal of time which the teacher utilizes in explaining abstract concepts and things.

\subsection{Obstacles in the utilization of community resources}

These are hindrances that could interfere in the effectiveness of teaching and learning in Nigerian schools, according to Edinyang (2018);

(1) The invitation of resource persons may take time to be realized.

(2) The organization of visitation is not frequent because of cost implications.

(3) Government interest in financing research in science and technology at the expense of social studies is a major hindrance.

(4) With the recruitment of non-professionally trained social studies teachers in junior secondary schools in a large number, the objectives of community resources utilization may be misguided.

(5) Students when not properly guided will abuse the objectives of the use of community resources as pleasure seeking venture.

\subsection{The factors that hinders the utilization of instructional materials and resources in social studies} teaching-learning process

In the teaching and learning process of social studies discipline or as a subject matter for effectiveness in classroom pedagogy, it is important to know that despite the usefulness of the instructional materials and resources certain factors still hinders its applicability. According to Mezieobi (2008), outline the following factors as hindrances to the utilization of instructional materials they include;

1. The teacher's lack of enthusiasm or commitment to effective social studies teaching.

2. Lack of a teacher's familiarity with a given instructional material or resources.

3. Lack of knowledge of the operational techniques.

4. A teacher's laziness in either utilizing appropriate materials and resources or improvising instructional materials from local materials.

5. Lack of, or inadequate funds to procure or produce instructional materials and the lethargy on the part of schools to generate supplemental sources of income for this and other purposes.

6. Previous embarrassment due to wrong use of materials and resources.

7. Lack of maintenance culture.

8. Materials or resources not being within the easy reach of the social studies teacher.

9. Lack of co-operation on the part of resources persons in the community.

10. Unavailability of transport facilities to undertake educational trips or to arrange for the invitation of resources persons.

\subsection{The role of the social studies teacher for organization and inviting resource person}

For the effectiveness of teaching and learning social studies as a discipline in classroom pedagogy the social studies teacher needs to organize and invite a resource person that will aid in boosting the teaching of social studies, which enable the learners learn adequately. According to Mezieobi (20o8) he listed the procedure to organize and invite a resource person to a social studies classroom. 
1. The social studies teacher must respect constituted authority and for the approval of the proposal, acquaint the principal or vice-principal of the school, whoever is directly in-charge of academic matters. This information communicated to the school authority, helps them prepare in advance to receive the expected educational visitor.

2. Before contemplating to invite a source person to the school, the social studies teacher must have compiled a list of resource personnel within and around the school community from where he would, from time to time, invite educational visitors to the school.

3. The teacher must ensure that the resource person being invited has some expertise and skills in his vocation as to make his talk meaningful.

4. The social studies teacher reaches the would-be resource person to request him to give a talk on a particular learnable activity.

5. The teacher also informs the proposed resource person of the specific duration of the talk or how long the talk is to last, the age range of the students and their level of understanding. The resource person should also be informed to expect questions from learners.

6. The teacher should prepare the class for the talk through informing them of the expected educational visitor and what his subject of discussion would be.

7. At the close of the talk, the teacher should write a formal thank you letter to the resource person on behalf of the principal and the school in appreciation of his magnanimity.

8. Follow-up activities and discussions should take place. This includes evaluating the lesson or learning experience.

\subsection{Criteria for selecting instructional materials and resources for social studies classrooms}

The use of instructional materials and resources in the social studies classrooms is not new, it is not chance thing or done haphazardly, but the usage of instructional materials and resources is of great importance to social studies teaching and interactive process which is planned adequately and guided in order to achieve its objectives. According to Mezieobi (2002) slated some of the following criteria for selecting social studies instructional materials, they include:

(1) Appropriateness of instructional materials to the attainment of specified instructional objectives

(2) Are the instructional materials relevant to the better understanding of the content/learning of experiences being taught?

(3) How do they (the instructional materials) help in the effective utilization of social studies teaching methods?

(4) Availability of the instructional material in terms of easy reach

(5) Are the instructional materials relatively inexpensive in terms of low cost or affordability?

(6) Do the selected instructional materials offer variety in instructional materials usage?

(7) Is the instructional materials bias or indoctrination free?

\subsection{Sources of social studies instructional materials}

There are various varieties of sources of social studies instructional material that the teachers are exposed to ensure that the teaching and learning of social studies in the classroom is greatly achieved. According to Mezieobi (2002) said that there are a wide variety of sources from which a plan-oriented, committed and determined social studies teacher draws the appropriate instructional materials for his/her teaching. These are:

(1) Market sources: Here commercially produced instructional materials such as textbooks, hardware and software may be bought from open markets in educational circumstances where their usefulness in adequate funding of the education industry.

(2) Educational resource centres/places/libraries: A number of educational resources centres are available in some tertiary institutions and in most states of the federal republic of 
Nigeria.

(3) Community/society: Instructional materials are plenty in communities that house our schools. Social studies teachers who are committed to sensitizing the social studies students to real life in their social world take the students to the resources places in the communities and/or invite resource persons in the community to the school.

(4) Improvisation: In the absence of commercially produced ready-made instructional materials, creative social studies teachers and students can improvise a good number of instructional materials given adequate motivation and congenial school climate.

(5) School's social studies laboratory: Relevant instructional materials that have been acquired from the market or produced or developed or improvised by skillful social studies teachers and students are housed in school's social studies laboratory from where they could be taken and made use of in the classroom setting, should the need arise for the use of any or some of them.

\subsection{Instructional materials for effectiveness in-classroom pedagogy}

From the forgoing, it is thus expected that these concepts and conceptual frameworks are to function as different focal points as it is not only the language that is needed but most subject matter or content of social studies are expressed in the respect of which the young learners are helped and guided to develop the immediate fundamental knowledge and positive attitudes which they would use to develop and buttress their own rational behavior, as effective and efficient citizens sooner or later within the nearest future, with the Nigeria political and economic framework. Any prospects of the improvement, development in the classroom image of social studies curriculum demands that the professional and trained social studies teacher of the subject must subscribe and conform himself/herself to the instructional demands and curricular activities to the subject area. Thus, the trained and professional teacher must, of necessity, put up with view of the language of his subject area, underscores skillfulness in consonance with the expanded meanings and understanding of the interrelationships and interconnections from the aforementioned theories.

Following the consideration of its multi-disciplinary and interdisciplinary emphases, classroom work in the social studies must move towards a new fusion in conveying the components parts of the curriculum into some articulate outline so that several kinds of disciplined inquiry and thought which stands upon the practical activity of education can be emphasized in order that new kinds of understanding be generated, Okam, (1989). The innovation/improvement arising from the arrangement and movement has to de-emphasize structures of the individual subject disciplines, to a larger degree. In the favour of more pressing issues, constraints and problems of life itself. According to Bruner, (1971) cited in Okam (2002) envisaged curriculum has to be vitally concerned with the growing experience of young learners and students with the enrichment of their instinctive hold on the conditions of life.

A very important instructional demand of the curricular process of social studies which is reflected in the foregoing considerations which is mandated to exert much needed positive impact for the future development and advancement of the subject area that has to do with a more functional use, on the part of the teachers who communicate materials and resources, equipment, the refinements of tools and facilities, the methods and strategies for the realization of a improved results in the particular subject area. According to Joof and Okam (1991) cited in Okam (2002), thus the social studies teachers are willy-nilly bound to display a mastery of a variety of skills and knacks for using and manipulating instructional media and resources for the purpose of achieving and satisfying important needs and objectives with particular reference to their students in terms of the following namely:

(1) An awareness and knowledge regarding employment of a variety of signs and symbols for construction and construing visual impressions of real life situations and for building vocabulary. 
(2) An acquisition of certain skills necessary for communicating ideas and vital information.

The place for a functional variety of instructional materials and resources for effectiveness and better achievement of classroom operation in social studies cannot be exhaustive. These media equipments constitute vital features of our classroom and are essentially designed to ease and bring about effectiveness in communication between the teachers and the learners. The chalk board could be used to build elements of processes and explanations classroom wise which may eventually make the learner to concentrate on the main points involved in order to arrive at the desired outcomes of learning activities.

Films are useful in the provision of visual impressions of the realities behind the role of a variety of symbols and are therefore designed to assist learners in building a requisite vocabularies which will enable them establish appreciation, rhythms and relationships amongst diverse phenomena. According to Ikwumelu (1988), social studies teachers can use films and filmstrips for satisfying the following needs with particular reference to their pupils, namely:

(1) Communicating information

(2) Changing attitudes

(3) Developing skills

(4) Whetting interest and raising problems

In conclusion from the forgoing, the purpose of making the visual components of textbooks functional is in a bid to attain the desired aims of social studies in classroom pedagogy. The teachers must not only seek or call the attention of the students or learners but rather seek to help the students to develop and practice skills which are of high necessity in terms of reading and interpreting them.

The work above with the social relevance of the philosophy of social studies education has been able to $\mathrm{x}$-ray the instructional materials and resources that are of direct relevance to the social studies interactive process in Nigerian schools at this stage of our development.

Social studies instructional materials and resources such as human and non-human resources are abound in and around the community in which our schools are situated. The social studies teachers should tap these available resources to their maximum advantage in the teaching and learning process.

The dependence on the high level of technology material such as television and radios for social studies instructional effectiveness in Nigeria at this point of our development metamorphosis is not only unrealistic, it will impede the proper institutionalization of social studies education.

\section{Recommendations}

It is imperative to realize that the process of teaching and learning for effectiveness in the classroom settings depends widely on the teacher, who is seen as the driver of the vehicle called classroom. The teachers' behaviours, attitudes are prerequisites to enhancing and impacting into the lives of the students either positively or negatively. Some of the behaviours and attitudes are thus;

1) The teacher must exhibit attitude and conducts which reflects attitude to work, commitment to a given task, cordiality in relationship with students, colleagues, such that these attitudes and behaviours serves as a mirror to the students which use in assessing the teacher, which the students emulates.

2) The teacher should ensure that the social studies concepts should focus on values of education. Effective learning derived from social studies teachings brings about acceptable behavioural conduct application.

3) The teacher ought to have a perfect hold; control of the classroom by organizing lessons, actively engaging of the learning and the instruction should be rewarding learning experiences.

4) The teacher's use of divergent instructional materials will provide the learners with an opportunity of multiple learning experiences which will arouse their interest in the 
classroom.

5) The teacher should ensure that the students are actively involved in the classroom interactive relationship, as the techniques improves the teaching-learning process, fertilization of ideas and clarification of complex topics and misunderstood concept could be achieved as interactive strategy is employed in the classroom pedagogy.

6) Instrumental materials and community resources should be utilized and made meaningful to lesson objectives. Practical application of knowledge facilitates teaching of social studies, improves retention, and challenges the mental alertness of the teacher, students and the decision making skills of learners are improved upon.

7) The use of supportive group projects and assignment increases team spirit in social studies classroom participation among students.

8) It enhances sharing of ideas and tolerance, it improves and develops cooperation and collective skills to work which facilitates good conducts and sharpens positive attitudes.

\section{References}

Alaezi, O. (1990). Groundwork of teaching strategies in Nigeria. Jos: Fab Enieh (Nig) Ltd.

Bruner, J. S. (1971). The relevance of education. London: Allen \& Unwin.

Dubery, D. L. \& Barth, J. L. (1980). Social studies: The inquiry Method Approach. Lagos: Thomas Nelson and Sons Ltd.

Edinyang, S. D. \&Effiom, V. N. (2018). Social studies methods, materials and resources. Calabar: University of Calabar Press.

Ezegbe, M. O. (1988). Foundations of social studies.Umuahia: Danton Publishers.

Ikwumelu, S. N. (1988). An introduction to social studies for higher education: Onitsha: Network Publishers Ltd.

Kissock, C. (1981). Curriculum planning for social studies teaching. New York: John Wiley and Sons.

Mezieobi, K. A. (1992). Indigenous social studies education in Nigeria. Its history, goals, content, methods and effectiveness. Owerri: Acadapeak Publishers.

Mezieobi, K. A. (2008). Social studies in Nigeria. Teaching methods, instructional materials and resources. Owerri: Acadapeak.

Mezieobi, K.A. (1992).Nature and purpose of social studies in understanding social studies education in Nigeria. Warri: Genteel Publishing Co.

Okam, C. C. (1989). Exploring the language of the social studies: A case for a rationalization of classroom instructions on the Nigerian educational scene.Nigerian Journal of Social Studies, 1(1 \& 2).

Okam, C. C. (2002). Readings in new developments in Nigerian education issues and insights. Jos: Deka Publication.

Ololobou, Y. P. (1999). Dimensions of social studies. Pankshin: Academic Trust Fund.

Uchegbu, U. C., Obilo, (1997). Social studies methodology. Owerri: Lasen Nig. Ltd. 